\title{
Chemical composition, antibacterial and antifungal activities of Cinamomum bejolghota bark oil from Thailand
}

\author{
Piyamas Atiphasaworn, Sakon Monggoot, Patcharee Pripdeevech* \\ School of Science, Mae Fah Luang University, Chiang Rai 57100, Thailand.
}

\begin{tabular}{l} 
ARTICLE INFO \\
\hline Article history: \\
Received on: 09/02/2017 \\
Accepted on: 24/03/2017 \\
Available online: 30/04/2017 \\
\hline Key words: \\
Cinnamomum bejolghota, \\
essential oil, antibacterial, \\
antifungal, phytochemical \\
composition, 1,8-cineole.
\end{tabular}

\section{INTRODUCTION}

Volatile components of essential oils are mainly represented by terpenoids, phenylpropanoids or benzenoids, fatty acid derivatives and amino acid derivatives (Dudareva et al., 2006). Volatile components of essential oils possess potential antimicrobial and insecticidal activities against pathogens including those causing human pathogenic diseases and crop spoilage in agriculture (Singh \& Maurya, 2005). Use of essential oils as antimicrobial agents is environmentally safe and economical. In addition, essential oils from various parts of plants are widely used for gargles in throat infection, skin care (Gutiérrez et al., 2008), beauty treatments (Price, 2003), herbal medicines (Schultz et al., 2001), aromatherapy (Price, 2003), cosmetics (Tisserand \& Young, 2013) and perfumery applications (Nielsen \& Rios, 2000). Essential oil of Cinnamomum plant, belonging to the Lauraceae family, is obtained from its leaves and barks and is widely used as a flavoring agent in food, as well as for cosmetic and

Corresponding Author

Patcharee Pripdeevech, School of Science, Mae Fah Luang University, Chiang Rai 57100,Thailand.Email: E-mail:patcharee.pri@ mfu.ac.th pharmaceutical applications (Sudmoon et al., 2014). The essential oil of Cinnamomum genus plants contained the great antimicrobial (Ooi et al., 2006), antifungal (Giordani et al., 2006), antiinflammatory (Miguel, 2010) and antixidant (Jayaprakasha et al., 2003) properties. Cinamomum bejolghota (Buch.-Ham.) is a medicinal plant, apply as the treatment of a cough, cold, toothache, liver complaints (Rao, 1979). The plant is widely distributed in China, Vietnam, Sri Lanka, Madagascar, India and East of Thailand (Li et al., 2013). Baruah et al., 1997 reported linalool as a major volatile in essential oil of $C$. bejolghota leaf and panicle cultivated in India, whereas $\alpha$-terpineol and $E$-nerolidol were found as the main components in its stem bark oil. Conversely, high amounts of 1,8-cineole and $\alpha$-terpineol were detected in essential oil of $C$. bejolghota bark collected from different areas in India (Choudhury et al., 1998). Only few studies have identified volatile profiles of $C$. bejolghota essential oil, though there is no previous study reporting the antimicrobial and antifungal properties of $C$. bejolghota oil. The aim of this study was to investigate the chemical composition of $C$. bejolghota oil from Thailand, to provide baseline data on its antibacterial and antifungal properties, and to predict its usefulness as a natural antimicrobial and antifungal agent in postharvest processing. 


\section{EXPERIMENTAL}

\section{Plant material}

Stem bark of $C$. bejolghota (Buch.-Ham.) was collected in April 2015 from Trat province, Eastern Thailand and air dried for 7 days. Voucher herbarium specimen (MFLU No. 10000) of the 1-year old plant was identified and deposited at the Mae Fah Luang University Botanical Garden, Chiang Rai, Thailand.

\section{Extraction of essential oil and chemical composition analysis}

One hundred grams of $C$. bejolghota dried bark were subjected to hydrodistillation for $4 \mathrm{~h}$ using a Clevenger-type apparatus. The essential oils were dried using anhydrous sodium sulfate. The chemical composition of $C$. bejolghota essential oil was carried out on a Hewlett Packard model HP6890 gas chromatograph (GC) (Agilent Technologies, Palo Alto, CA, USA) equipped with an HP-5MS (5\% phenylpolymethylsiloxane) capillary column $(30 \mathrm{~m} \times 0.25 \mathrm{~mm}$ i.d., film thickness $0.25 \mu \mathrm{m}$; Agilent Technologies, USA) employed with an HP model 5973 mass selective detector (MS). The oven temperature was programmed at an initial temperature of $60{ }^{\circ} \mathrm{C}$ prior ramping at a 3 ${ }^{\circ} \mathrm{C} / \mathrm{min}$ until a maximum of $200{ }^{\circ} \mathrm{C}$ was reached. The temperatures of the injection and detection steps were set at 250 and $280{ }^{\circ} \mathrm{C}$, respectively. Helium was used as the carrier gas with a flow rate of $1 \mathrm{~mL} / \mathrm{min}$. The EI mass spectra were collected at $70 \mathrm{eV}$ ionization voltages over the range of $\mathrm{m} / \mathrm{z}$ 29-300. The electron multiplier voltage was $1150 \mathrm{~V}$. The ion source and quadrupole temperatures were set at $230{ }^{\circ} \mathrm{C}$ and $150{ }^{\circ} \mathrm{C}$, respectively. One microliter of $C$. bejolghota essential oil was dissolved in n-hexane $(1: 100 \mathrm{v} / \mathrm{v})$ prior to injection into the GC-MS system with a split ratio of 1:200. Identification of essential oil composition was accomplished by comparison between their relative retention indices ( $\mathrm{RI}$ ) to $\mathrm{C}_{8}-\mathrm{C}_{16} n$-alkanes, and using a comparison of the mass spectra of individual components with the reference mass spectra in the W8N08 and NIST08 databases, and published literature. Quantification of all identified components was investigated by using a percent relative peak area.

\section{Antibacterial activity assay}

Antibacterial activities of $C$. bejolghota bark oil were investigated against 6 bacterial pathogens representing three Gram-negative bacteria (Salmonella typhimurium TISTR292, Pseudomonas aeruginosa TISTR781 and Escherichia coli TISTR780) and three Gram-positive bacteria (Staphylococcus aureus TISTR1466, Bacillus subtilis TISTR008 and B. cereus TISTR687). All bacterial pathogens were obtained from the Thailand Institute of Scientific and Technological Research, Thailand. The antibacterial activities of $C$. bejolghota essential oil were determined by using a disc diffusion assay (Ross et al., 2013). Each bacterial strain was cultured in tryptic soy agar medium at $37{ }^{\circ} \mathrm{C}$ which the single colony was collected and further adjusted to $0.5 \mathrm{McFarland}$ standard. Subsequently, the bacteria were swabbed on a Mueller Hinton agar medium plate by using sterilized cotton. Essential oil of $C$. bejolghota bark was diluted by two-fold dilution method with dichloromethane to perform the final concentrations of $1000,500,250,125,62.50$ $31.25,7.81$ and $3.91 \mu \mathrm{g} / \mathrm{mL}$, respectively. Twenty microliters of $C$. bejolghota bark oil with different concentrations were loaded into a $6 \mathrm{~mm}$-diameter sterile paper disc (Whatman ${ }^{\mathrm{TM}}$, USA) and then placed on Mueller Hinton agar medium plate. All plates were incubated at $37{ }^{\circ} \mathrm{C}$ for $24 \mathrm{~h}$. The inhibition zone diameter of different $C$. bejolghota oil concentrations was measured in millimeters. Minimum inhibitory concentration (MIC) values inhibiting bacterial growth were also determined. Penicillin was used as positive control in this study. All experiments were performed in triplicate.

\section{Antifungal activity assay}

The plant pathogenic fungi used in this study were obtained from the Institute of Excellence in Fungal Research, Mae Fah Luang University, Chiang Rai, Thailand including Collectotrichum asianum MFULCC10-0286, C. fruticola MFLUCC10-0288, C. tropica MFLUCC11-0114, and C. magna MFLUCC12-0713. The antifungal activities of $C$. bejolghota essential oil were determined by using the disc diffusion method (Murray et al., 1995). Essential oil of C. bejolghota bark was prepared by using two-fold dilution method at final concentrations of $1000,500,250,125,62.5,31.25,7.81$ and $3.91 \mu \mathrm{g} / \mathrm{mL}$. Initially, all pathogenic fungi were cultured on potato dextrose agar (PDA) media and incubated at $30{ }^{\circ} \mathrm{C}$ for 1 week. A plug of 1 -week old fungal culture ( $6 \mathrm{~mm}$ diameter) of each strain was placed on the center of PDA medium plates. Ten microliters of different essential oil concentrations were individually loaded into $6 \mathrm{~mm}$ diameter sterile paper disc (Whatman ${ }^{\mathrm{TM}}$, USA) and then placed on plates containing a plug of fungal culture. The plates were incubated at $30{ }^{\circ} \mathrm{C}$ for a week. The mycelial fungal growth inhibition of each fungal strain was calculated according to the following equation: Percentage of inhibition $(\%)=100$ [(1-radical growth of treatment $(\mathrm{mm})$ /radical growth of control $(\mathrm{mm})]$. All experiments were performed in triplicate. In addition, MIC values inhibiting mycelial fungal growth were also determined.

\section{Data analysis}

The experiments were performed in triplicate and are reported as mean \pm standard deviation. Quantitative variations were analyzed by one-way ANOVA (at $\mathrm{P}<0.05$ ). Duncan's Multiple Range test combined with the Statistical Analysis System (Sas, 1990) was used to study the differences among samples.

\section{RESULTS AND DISCUSSION}

The extraction yield of $C$. bejolghota bark oil was $1.01 \% \mathrm{v} / \mathrm{v}$ with pale yellow color. Thirty-six volatile components were detected in the essential oil of $C$. bejolghota bark, accounting for $97.96 \%$ of the total oil composition. Oxygenated monoterpene and monoterpene were considered as the major compounds as shown in Table 1. The major constituent was 1,8-cineole (40.24\%), followed by $\gamma$-terpineol $(15.41 \%)$, borneol $(7.86 \%)$, 
terpinen-4-ol (7.55\%) and $\alpha$-pinene $(6.58 \%)$, respectively (Adams, 1995; König et al., 1999). Volatile compounds represented aromatic profile of Cinnamomum plant were also detected such as $Z$-cinnamaldehyde, $\alpha$-amyl cinnamyl alcohol, $E$-isoamyl cinnamate, E-2-hexyl cinnamaldehyde, benzyl cinnamate and phenethyl cinnamate. The volatile profiles in this study differed from the study of Baruah et al., 1997 and Choudhury et al., 1998 whereby $\alpha$-terpineol and $E$-nerolidol were identified as the principle components in bark oil of $C$. bejolghota. The high variation of essential oil components between locations could be due to differences in the time of harvesting and extraction method (Heywood, 2002). Extrinsic variables based on geographic origin include climatic and soil-growth conditions, both of which may cause environmental stress and variability of chemical composition (Vokou et al., 1993).

Table 1: Chemical composition of $C$. bejolghota bark oil with the percentage of content obtained by hydrodistillation.

\begin{tabular}{|c|c|c|c|}
\hline No. & Compound & RI & \%Peak area \\
\hline 1 & $\alpha$-Thujene & 930 & 0.07 \\
\hline 2 & $\alpha$-Pinene & 932 & 6.58 \\
\hline 3 & Camphene & 946 & 3.38 \\
\hline 4 & Sabinene & 969 & 0.08 \\
\hline 5 & $\beta$-Pinene & 971 & 3.23 \\
\hline 6 & Myrcene & 981 & 0.78 \\
\hline 7 & $\delta$-3-Carene & 1005 & 0.09 \\
\hline 8 & $\alpha$-Terpinene & 1014 & 0.69 \\
\hline 9 & 1,8-Cineole & 1026 & 40.24 \\
\hline 10 & $E$ - $\beta$-Ocimene & 1044 & 0.07 \\
\hline 11 & $\gamma$-Terpinene & 1049 & 0.81 \\
\hline 12 & cis-Sabinene hydrate & 1064 & 0.08 \\
\hline 13 & $\rho$-Mentha-2,4(8)-diene & 1079 & 0.34 \\
\hline 14 & $\rho$-Cymenene & 1089 & 0.09 \\
\hline 15 & Linalool & 1095 & 0.11 \\
\hline 16 & endo-Fenchol & 1114 & 0.13 \\
\hline 17 & cis- $\rho-M e n t h a-2-e n-1-o l$ & 1118 & 0.08 \\
\hline 18 & Camphor & 1141 & 1.17 \\
\hline 19 & Camphene hydrate & 1140 & 0.19 \\
\hline 20 & Isoborneol & 1150 & 0.05 \\
\hline 21 & Borneol & 1163 & 7.86 \\
\hline 22 & Terpinen-4-ol & 1174 & 7.55 \\
\hline 23 & $\gamma$-Terpineol & 1191 & 15.41 \\
\hline 24 & Verbenone & 1204 & 0.17 \\
\hline 25 & Z-Cinnamaldehyde & 1217 & 0.26 \\
\hline 26 & Thymol methyl ester & 1232 & 0.05 \\
\hline 27 & Chavicol & 1247 & 0.06 \\
\hline 28 & trans-Piperitone epoxide & 1253 & 0.05 \\
\hline 29 & Geraial & 1262 & 0.05 \\
\hline 30 & Dihydro-linalool acetate & 1275 & 0.11 \\
\hline 31 & Isobornyl acetate & 1280 & 0.11 \\
\hline 32 & Safrole & 1288 & 0.09 \\
\hline 33 & Geranyl formate & 1299 & 0.09 \\
\hline 34 & Dihydro-carveol acetate & 1306 & 0.09 \\
\hline 35 & Limonene aldehyde & 1327 & 0.05 \\
\hline 36 & $\delta$-Elemene & 1333 & 0.05 \\
\hline 37 & $\alpha$-Cubebene & 1339 & 0.05 \\
\hline 38 & Eugenol & 1359 & 0.05 \\
\hline 39 & $\alpha$-Ylangene & 1373 & 0.11 \\
\hline 40 & $\beta$-Elemene & 1383 & 0.05 \\
\hline 41 & $\alpha$-Chamipinene & 1396 & 0.09 \\
\hline 42 & $\alpha$-Gurjunene & 1409 & 0.06 \\
\hline 43 & $\alpha$-trans-Bergamotene & 1433 & 0.08 \\
\hline 44 & Prezizaene & 1444 & 0.08 \\
\hline 45 & $\alpha$-Humulene & 1452 & 0.05 \\
\hline 46 & $\alpha$-Zingiberene & 1491 & 0.07 \\
\hline 47 & Gernacrene A & 1506 & 0.21 \\
\hline 48 & 7-epi- $\alpha$-Selinene & 1520 & 0.22 \\
\hline
\end{tabular}

\begin{tabular}{|c|c|c|c|}
\hline 49 & $\delta$-Cadinene & 1522 & 0.11 \\
\hline 50 & Zonarene & 1528 & 0.55 \\
\hline 51 & $\alpha$-Cadinene & 1537 & 0.07 \\
\hline 52 & Selina-3,7(11)-diene & 1545 & 0.19 \\
\hline 53 & trans-Cadinene ether & 1559 & 0.16 \\
\hline 54 & Himachalene epoxide & 1579 & 0.06 \\
\hline 55 & Neryl isovalerate & 1582 & 0.14 \\
\hline 56 & Guaiol & 1602 & 0.11 \\
\hline 57 & $\beta$-Cedrene epoxide & 1622 & 0.64 \\
\hline 58 & epi- $\alpha$-Cadinol & 1637 & 0.48 \\
\hline 59 & Isoamyl geranate & 1651 & 0.55 \\
\hline 60 & 5-iso-Cedranol & 1671 & 0.47 \\
\hline 61 & $\alpha$-Amyl cinnamyl alcohol & 1682 & 0.27 \\
\hline 62 & $Z$ - $\alpha$-trans-Bergamotol & 1690 & 0.07 \\
\hline 63 & Eumesm-7(11)-en-4-ol & 1697 & 0.09 \\
\hline 64 & Longifolol & 1715 & 0.11 \\
\hline 65 & iso-Longifolol & 1732 & 0.08 \\
\hline 66 & $E$-Isoamyl cinnamate & 1740 & 0.09 \\
\hline 67 & E-2-Hexyl cinnamaldehyde & 1750 & 0.05 \\
\hline 68 & Benzyl benzoate & 1762 & 0.06 \\
\hline 69 & epi-Cyclocolorenone & 1777 & 0.11 \\
\hline 70 & $Z$ - $\alpha$-trans-Bergamotol acetate & 1793 & 0.13 \\
\hline 71 & $\alpha$-Bisabolol acetate & 1801 & 0.05 \\
\hline 72 & $\beta$-Chenopodiol & 1810 & 0.06 \\
\hline 73 & Acorone & 1824 & 0.08 \\
\hline 74 & 7-Hydroxy coumarin & 1841 & 0.06 \\
\hline 75 & $Z, Z$-Farnesyl acetone & 1858 & 0.07 \\
\hline 76 & $Z$-Spiroether & 1874 & 0.10 \\
\hline 77 & 8S,14-Cedranediol & 1886 & 0.10 \\
\hline 78 & Cataponone & 1896 & 0.05 \\
\hline 79 & 11,12-Dihydroxy valencene & 1918 & 0.05 \\
\hline 80 & Carissone & 1924 & 0.05 \\
\hline 81 & Isohibaene & 1935 & 0.05 \\
\hline 82 & Phytol & 1948 & 0.08 \\
\hline 83 & Columellarin & 1954 & 0.09 \\
\hline 84 & 3Z-Cembrene A & 1964 & 0.07 \\
\hline 85 & 4-Methoxy stilbene & 1991 & 0.09 \\
\hline 86 & $Z, E$-Geranyl linalool & 1998 & 0.09 \\
\hline 87 & 13-epi-Manool oxide & 2007 & 0.08 \\
\hline 88 & Juvibione & 2016 & 0.12 \\
\hline 89 & Bergaptene & 2050 & 0.09 \\
\hline 90 & Sclareolide & 2075 & 0.09 \\
\hline 91 & Benzyl cinnamate & 2098 & 0.09 \\
\hline 92 & Laurenan-2-one & 2117 & 0.09 \\
\hline 93 & $E$-Isoeugenyl benzyl ether & 2128 & 0.09 \\
\hline 94 & Abienol & 2149 & 0.07 \\
\hline 95 & Phenethyl cinnamate & 2179 & 0.08 \\
\hline
\end{tabular}

$\mathrm{RI}$, linear temperature program retention index on DB-5 column.

The antibacterial activities of $C$. bejolghota bark oil in terms of inhibition zone diameter and MIC are demonstrated in Table 2. The most sensitive bacterial strain was E. coli TISTR780 followed by $P$. aeruginosa TISTR781, $S$. aureus TISTR1466, $B$. subtilis TISTR008, S. typhimurium TISTR292 and B. cereus TISTR687.

Table 2: Antibacterial activities of essential oils of $C$. bejolghota bark oil and penicillin.

\begin{tabular}{lllll}
\hline \multirow{2}{*}{ Bacteria } & \multicolumn{2}{l}{ inhibition Diameter $(\mathbf{m m})$} & \multicolumn{2}{l}{ MIC $(\boldsymbol{\mu g} / \mathbf{m L})$} \\
\cline { 2 - 5 } & Essential oil & Penicillin & Essential oil & Penicillin \\
\hline Gram-positive & & & & \\
B. cereus & $7.87 \pm 1.94$ & $5.08 \pm 0.91$ & 62.50 & 3.91 \\
B. subtilis & $7.47 \pm 2.05$ & $3.75 \pm 1.22$ & 31.25 & 3.91 \\
S. aureus & $7.57 \pm 1.53$ & $10.08 \pm 0.29$ & 31.25 & 7.81 \\
Gram-negative & & & & \\
E. coli & $10.43 \pm 1.11$ & $6.41 \pm 0.56$ & 31.25 & 7.81 \\
P. aeruginosa & $7.83 \pm 1.95$ & $3.75 \pm 1.20$ & 31.25 & 3.91 \\
S. typhimurium & $9.73 \pm 1.25$ & $4.55 \pm 1.10$ & 62.50 & 7.81 \\
\hline
\end{tabular}


The MIC of $C$. bejolghota bark oil against various bacterial species ranged between 31.25 and $62.25 \mu \mathrm{g} / \mathrm{mL}$. The antifungal properties of $C$. bejolghota bark oil against four postharvest pathogenic fungi and MIC values are shown in Table 3. The $C$. bejolghota bark oil displayed the strongest antifungal activity against $C$. asianum, with MIC of $125 \mu \mathrm{g} / \mathrm{mL}$, while the MIC values against other postharvest pathogenic fungi ranged between 250 and $500 \mu \mathrm{g} / \mathrm{mL}$. Although antimicrobial activities of Cinnamomum spp. essential oils have been widely reported, the effectiveness of $C$. bejolghota bark oil on pathogenic species has been less studied.

Table 3: Percentage of growth inhibition of Colletotrichum sp. fungi by C. bejolghota bark oil.

\begin{tabular}{ccc}
\hline Fungi & Radical growth inhibition $(\boldsymbol{\%})$ & MIC $(\boldsymbol{\mu g} / \mathbf{m L})$ \\
\hline C. asianum & $30.86 \pm 2.14$ & 125 \\
C. fruticola & $13.79 \pm 3.45$ & 250 \\
C. magna & $24.24 \pm 2.62$ & 500 \\
C. tropica & $17.33 \pm 2.31$ & 250 \\
\hline
\end{tabular}

The mechanisms of the antimicrobial action of essential oil from plants are still not clearly understood. Terpenoids are major components of essential oil possessing hydrophobic and hydrophilic parts with different functional groups. This enables terpenoids to simply transport across bacterial or fungal cell walls and interact with the microbes (Burt, 2004; Koroch et al., 2007). The antimicrobial activity of $C$. bejolghota bark oil may be correlated to the diversity of its bioactive compounds. These include 1,8-cineole (comprising $40.24 \%$ of the oil) and $\gamma$-terpineol $(15.41 \%)$ in the essential oil, both of which have potent antibacterial and fungicidal activities (Carson et al., 2002; Hendry, Worthington et al., 2009; Wang et al., 2012). Mahboubi and Kazempour, 2009 reported that antibacterial activity of whole essential oil was greater than that obtained from major components alone. The great antimicrobial activity of $C$. bejolghota bark oil could be also contributed to a combination of minor components including linalool, borneol, isoborneol, $\alpha$-pinene, $\beta$-pinene and camphor (Koutsoudaki et al., 2005; Santoyo et al., 2005; Sivropoulou et al., 1997). The strong antimicrobial activity against $E$. coli and $B$. cereus is particularly interesting, because both microbes are classified as human pathogens. According to the Advisory Committee on Dangerous Pathogens, both bacteria belong to the second hazard group of biological agents which pose risk to human health. Moreover, growth inhibition of these bacteria is important because of their role in food contamination. In addition, strong antimicrobial activity was significant against $C$. asianum with $30.86 \%$ growth inhibition. Therefore, essential oil of C. bejolghota bark is a potential antibacterial and antifungal agent that may find wider applications in food industry and postharvest processing.

\section{CONCLUSIONS}

The present study indicated that essential oil obtained from the stem bark of $C$. bejolghota is rich in oxygenated monoterpenes, mainly 1,8-cineole, which constitutes $40.24 \%$ of the total oil composition. Biological evaluation revealed that the $C$. bejolghota bark oil possesses strong antibacterial and antifungal activities. $C$. bejolghota oil may be viewed as a bioactive natural product with cosmetic or postharvest production applications.

\section{ACKNOWLEDGEMENTS}

The authors express their gratitude to the Office of the Postgraduate Studies and the Scientific and Technological Instrument Center (STIC), Mae Fah Luang University for financial and GC-MS support respectively. I am grateful to Mae Fah Luang University Botanical Garden, Chiang Rai, Thailand for their help in the collection and identification of the C. bejolghota plant.

Conflict of Interests: There are no conflicts of interest.

\section{REFERENCES}

Adams RP. 1995, Identification of essential oil components by gas chromatography / mass spectroscopy, Illinois, USA. Allured Publishing Corporation.

Baruah A, Nath SC, Hazarika AK, Sarma TC. Essential Oils of the Leaf, Stem Bark and Panicle of Cinnamomum bejolghota (Buch.Ham.) Sweet. J Essent Oil Res, 1997; 9:243-245.

Burt S. Essential oils: their antibacterial properties and potential applications in foods-a review. Int J Food Microbiol, 2004; 94:223-253.

Carson CF, Mee BJ, Riley TV. Mechanism of action of Melaleuca alternifolia (tea tree) oil on Staphylococcus aureus determined by time-kill, lysis, leakage, and salt tolerance assays and electron microscopy. Antimicrob Agents Chemother, 2002; 46:1914-1920.

Choudhury S, Ahmed R, Barthel A, Leclercq PA. (1998). Composition of the bark and flower oils of Cinnamomum bejolghota (Buch.-Ham.) sweet from two locations of Assam, India. J Essent Oil Res, 1998; 10:245-250.

Dudareva N, Negre F, Nagegowda DA, Orlova I. Plant volatiles: recent advances and future perspectives. CRC Crit Rev Plant Sci, 2006; 25:417-440.

Giordani R, Regli P, Kaloustian J, Portugal H. Potentiation of antifungal activity of amphotericin B by essential oil from Cinnamomum cassia. Phytother Res, 2006; 20:58-61.

Gutiérrez RMP, Mitchell S, Solis RV. Psidium guajava: a review of its traditional uses, phytochemistry and pharmacology. J Ethnopharmacol, 2008; 117:1-27.

Hendry E, Worthington T, Conway BR, Lambert P. Antimicrobial efficacy of eucalyptus oil and 1,8-cineole alone and in combination with chlorhexidine digluconate against microorganisms grown in planktonic and biofilm cultures. J Antimicrob Chemother, 2009; 64:1219-1225

Heywood VH. 2002. The conservation of genetic and chemical diversity in medicinal and aromatic plants. In: Bilge S, ed. Biodiversity: biomolecular aspects of biodiversity and innovative utilization, New York: Springer 13-22.

Jayaprakasha GK, Jagan MRL, Sakariah, KK. Volatile constituents from Cinnamomum zeylanicum fruit stalks and their antioxidant activities. J Agric Food Chem, 2003; 51:4344-4348.

König WA, Bülow N, Saritas Y. Identification of sesquiterpene hydrocarbons by gas phase analytical methods. Flavour Fragr J, 1999; 14:367-378.

Koroch AR, Juliani HR, Zygadlo JA. 2007. Bioactivity of essential oils and their components. In: Ralf GB, ed. Flavours and fragrances, Heidelberg: Springer 87-115.

Koutsoudaki C, Krsek M, Rodger A. Chemical composition and antibacterial activity of the essential oil and the gum of Pistacia lentiscus Var. chia. J Agric Food Chem, 2005; 53:7681-7685. 
Li Yq, Kong Dx, Wu H. Analysis and evaluation of essential oil components of cinnamon barks using GC-MS and FTIR spectroscopy. Ind Crop Prod, 2013; 41:269-278.

Mahboubi M, Kazempour N. The antimicrobial activity of essential oil from Perovskia abrotanoides karel and its main components. Indian J Pharm Sci, 2009; 71:343-347.

Miguel MG. Antioxidant and anti-inflammatory activities of essential oils: a short review. Molecules, 2010; 15:9252-9287.

Murray PR, Baron EJ, Pfaller M, Tenover F, Yolken, RH, Morgan DR. 1995. Manual of Clinical Microbiology. Washington, USA: ASM Press.

Nielsen PV, Rios R. Inhibition of fungal growth on bread by volatile components from spices and herbs, and the possible application in active packaging, with special emphasis on mustard essential oil. Int J Food Microbiol, 2000; 60:219-229.

Ooi LS, Li Y, Kam SL, Wang H, Wong EY, Ooi VE. Antimicrobial activities of cinnamon oil and cinnamaldehyde from the Chinese medicinal herb Cinnamomum cassia Blume. Am J Chin Med, 2006; 34:511-522.

Price S. Aromatherapy for Common Ailments: How to Use Essential Oils--Such as Rosemary, Chamomile, and Lavender--To Prevent and Treat More Than 40 Common Ailments. New York, USA: Simon and Schuster.

Rao, R. 1979. Ethnobotanical studies on the flora of Meghalaya - some interesting reports of herbal medicines. In: Jain SK, ed. Glimpses of Indian ethnobotany. New Delhi: Oxford and IBH Publishing 137-148.

Ross JE, Scangarella-Oman N, Jones RN. Determination of disk diffusion and MIC quality control guidelines for GSK2251052: a novel boron-containing antibacterial. Diagn Microbiol Infect Dis, 2013; 75:437439.

Santoyo S, Cavero S, Jaime L, Ibanez E, Senorans F, Reglero G. Chemical composition and antimicrobial activity of Rosmarinus officinalis L. essential oil obtained via supercritical fluid extraction. J Food Prot , 2005; 68:790-795.

Sas S. 1990. STAT user's guide, version 6 SAS Institute. North Carolina, USA: SAS Institute Incorporated.
Schultz V, Hänsel R, Tyler VE. 2001. Rational phytotherapy: a physician's guide to herbal medicine. Texas, USA: Springer.

Singh G, Maurya S. Antimicrobial, antifungal and insecticidal investigations on essential oils: An overview. Nat prod radiance, 2005; 4:179-192.

Sivropoulou A, Nikolaou C, Papanikolaou E, Kokkini S, Lanaras T, Arsenakis M. Antimicrobial, cytotoxic, and antiviral activities of Salvia fructicosa essential oil. J Agric Food Chem, 1997; 45: $3197-$ 3201.

Sudmoon R, Chaveerach A, Sanubol A, Monkheang P, Kwanda $\mathrm{N}$, Aungkapattamagul S, Kaewdoungdee N. Identifying efficiency in herbal medicine Cinnamomum species (Lauraceae) using banding patterns and sequence alignments of $\mathrm{rpoB}, \mathrm{rbcL}$ and matK regions. J Med Case Rep, 2014; 41: 1094-1108.

Tisserand R, Young R. 2013. Essential oil safety ( $2^{\text {nd }}$ Edition): a guide for health care professionals. London, England: Churchill Livingstone.

Vokou D, Kokkini S, Bessiere JM. Geographic variation of Greek oregano (Origanum vulgare ssp. hirtum) essential oils. Biochem Syst Ecol, 1993; 21:287-295.

Wang W, Li N, Luo M, Zu Y, Efferth T. Antibacterial activity and anticancer activity of Rosmarinus officinalis L. essential oil compared to that of its main components. Molecules, 2012; 17: 2704-2713.

\section{How to cite this article:}

Atiphasaworn P, Monggoot S, Pripdeevech P., Chemical composition, antibacterial and antifungal activities of Cinamomum bejolghota bark oil from Thailand. J App Pharm Sci, 2017; 7 (04): 069-073. 